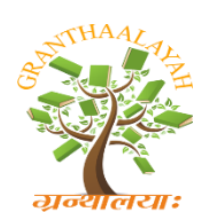

INTERNATIONAL JOURNAL OF RESEARCH GRANTHAALAYAH A knowledge Repository

Social

\title{
LOKSAMGRAH: AN AFFIRMATIVE THOUGHT FOR SOCIAL RECONSTRUCTION
}

\author{
Dr Jatin Bishoyi *1 \\ ${ }^{* 1}$ HOD, Department of Philosophy, Khallikote University, India
}

DOI: https://doi.org/10.29121/granthaalayah.v5.i4.2017.1817

\begin{abstract}
For Bhagavad-Gita, both individual and society as a whole is dependent on three principal conditions for their existence such as Niskama karma, Svadharma and Loksamgrah. Loksamgrah is used in a very comprehensive connotation as it not only looks at the collective well-being of this world but the universe as a whole. It is because in Loksamgrah the word 'Loko' does not mean only people of this world but all the beings of satyaloka, pitruloka, devaloka, bhurloka and other loka. In Gitarahasya Tilak points out, "The word 'Loksamgrah' has been used in the Bhagavad-Gita to mean the maintenance, not only of human beings, but that the human and all others spheres, such as of the Gods etc. should be maintained, and that they should become mutually beneficial". True to say the recommendation of Loksamgrah on our public life have triggered concerns that public services, ranging from physical world to metaphysical world could become more imperative but in fact, it only would have minimal impact on public life i.e. it only attempts to minimize distress and problems both at individual and society levels. As a whole it could only attempt to inculcate the values of public service and integrity attitude. Radhakrishnan points out that, "Loksamgrah stands for the unity of the world, the interconnectedness of society. If the world is not to sink into a condition of physical misery and moral degradation, if the common life is to be decent and dignified, religious ethics must control social action".
\end{abstract}

Keywords: Bhagavad-Gita; Loksamgrah; Social Reconstruction.

Cite This Article: Dr Jatin Bishoyi. (2017). "LOKSAMGRAH: AN AFFIRMATIVE THOUGHT FOR SOCIAL RECONSTRUCTION." International Journal of Research Granthaalayah, 5(4), 246-249. https://doi.org/10.29121/granthaalayah.v5.i4.2017.1817.

\section{Introduction}

Loksamgrah is an altruistic principle and this principle must be cultivated in human life for the purification and reformation of both individual and society. When we develop our egotism at an alarming rate besides looking at the maximum benefit of society, our life is maze filled with twist stand turns, crossroad and dead ends. So we must sacrifice our egoistic life for the benefit 
of the society. In J. S. Mill's language it is a transition from self- regarding action to other regarding action. In utilitarian language it is a sanction of morality from egoism to altruism. However the principle of Loksamgrah is not a kind of physical, religious, political and social sanctions but it is a moral sanction that is cultivated as an end in itself without the anticipation of any other means. Doing good to others and world as a whole should be only motive of every individual and in promoting this altruistic attitude is, indeed, indispensable for our own selfpurification and self- realizations. Vivekananda says, "The main effect of work done for others is to purify ourselves. By means of the constant effort to do good to others we are trying to forget ourselves; this forgetfulness of self is the one great lesson we have to learn in life. Every act of charity, every thought of sympathy and, every action of help, every good deed takes so much of self-importance away from our little selves and makes us think ourselves as the lowest and the least, and therefore they are all good. For Binova Bhave when we perform our action with selfpurification incessantly without any attachment for the sake of Loksamgrah, we will attempt perfect peace of life. He says, when Sattvik karma is done continuously the mind will get purified actively and will go on becoming gentle and subtle and will cease completely in the end. Activity will disappear but our actions for the sake of Loksamgrah to bring the people together and show them the path of righteousness will continue". Tilak interprets, "as the benefit of one's own atman also includes exerting oneself to the fullest extent of one's abilities, for the benefit of the all-pervading Atman, the Gita goes further and says that the Realization of the identity of the Brahman and the Atman ultimately resolves itself into bringing about Loksamgrah".

Application of Loksamgrah is, indeed, a moral crusade. For Binova Bhave, Loksamgrah believes in the principle of self-restraint and non-possession that promotes moral values in one's life. Loksamgrah does not mean following the wishes of the people. It means showing the people the path of pure morality.... Don't worry about the whole creation and the human race. Increase your moral strength eschews desire, least and anger from your mind. It must be performed as if one's duty without anticipation of result. A man has to bring about Loksamgrah merely as a duty. It is for the same reason that the Gita has used the rather longish phraseology of 'Lokasamgraham evapi sampasyam' i. e you must perform action, keeping in sight public welfare, instead of saying that 'Lokasamgahartha' means "for obtaining fruit in the shape of public welfare.

Loksamgrah must be performed as if one's duty without anticipation of result. In Gita it is pointed out that Janaka and other rules had achieved perfection by performing their assigned duties and even their subjects were taught how to perform their duties for the sake of lokosangraha. In $3^{\text {rd }}$ chapter of Gita, it states-

$$
\begin{aligned}
& \text { "karmani hi samsiddim } \\
& \text { Asthita janakadayah } \\
& \text { Lokasangrahm eva pi } \\
& \text { Sampasyan kartum arhasi }
\end{aligned}
$$

(Chapter 111-20)

Further, it is said that great men are the path maker who blare the trail that he internally follows. Great intellectuals and social reformers must adopt the attitude of lokosangraha so that others 
should follow it. It is similar to Kant's maxim of morality that "Act only on that maxim which thou canst will to be universal law"

Yad-yad acarati srestha

Tad tad eve taro janah

Sa yat pramanam kurute

Lokas tad anuvartate

(Chapter 111-21)

There is no moral slugfest in between Nirvrti and Pravrti as the life of Nivrti is a life of asceticism being apart from selfish desire and is involved in the social welfare and public work. Similarly the life of pravrti is a life of detachment and dispassion that does not mean giving up or feeling of repulsion for material objects rather it is a feeling of love, kindness, service, forgiveness and helpfulness without expectation which truly fulfill the objective of Loksamgrah. It is a matter of our attitude whether we choose the path of world (Pravrti) and the path of renunciation (Nivrti) and in both cases the objective is to how far we will work for the interest of the loko or people of both physical and meta physical world.

To add in this it is said that Loksamgrah doesn't teach that the problem of all people will be sorted out. Well-being of all or universal happiness is a pseudo idea and conundrum that physically and practically can't be possible. At best it believes in the utilitarian doctrine of greatest good of the greatest number (Bahujana Hitaya \& Bahujana Sukhaya). Moreover Loksamgrah is an affirmative attitude that will attempt to minimize the problem of society at best possible way. Russell says that, "what our world needs is the opposite, It needs rational creature hope; It needs something positive to live for. It needs 'Yes' feeling rather than 'No' feeling.".

The concept "Lokasmgraha" is intimately connected with the concepts svadharma and Niskama karma. Pursuit of svadarma is indispensible for desireless work (Karma-yoga). Sometimes it looks that both svadharma and karmayoga are inconsistent but this is not true. It is because desire less work doesn't mean work without any desire as desire is the crystallization of all human life concerns which make life worth living, axiological and meaningful rather it donates that we must work without any selfish desire that ultimately lead to the interest of all (Loksamgrah), A man must work in the virtue of public spirit and a public spirited man is always involved in the public welfare benefit earnestly and diligently. Public spirit is the common spirit. Annie Besant states, "Public spirit is the common spirit, the spirit of all the public, the spirit which is one in all the public; and the public spirited man is he who consciously or unconsciously realizes the oneness of the self in all the members of that public to which he belongs; who feels that the good and the evil of each are the good and the evil of one the members of that public and who acts accordingly, endeavoring to ameliorate the conditions of life for all".

For VinobaBhave, "a true karma yogi through Loksamgrah materializes two simultaneous aims of individual good as well as social good. For e.g. if a true karma yogi is engaged in the care of the cows, he will do the work with the idea of serving the society by providing it with plenty of milk and at the same time he will look to it as an opportunity to have a relationship of love with all the lower orders of beings". For this reason harmonious life of human beings become possible by identifying his dignity and talent, and performing duties as per the norms assigned to them in 
the society as a way to lead the life of Loksamgrah. Putting importance on svadharma the Gita states that one should discharge one's prescribed duties even though it is wrong without focusing others perfect duties.It states -

\author{
'Sreyansva dharma vigunah \\ Para dharmat svanusathitat \\ Sva dharma nidhanam sreyah \\ Para dharmo bhuyavahah
}

Tilak says, "Whatever the arrangement of society may be, one should enthusiastically perform all the duties which have come to one's share, according to one's status in shape of the happiness of all created things."

Lastly, in a very optimistic expression it is transpired that the notion of Loksamgrah in the society needs to be spread. Unless there is a common effort to motivate people for Loksamgrah, we will all get caught in the frizzy of our hectic daily schedule, be unhappy and egoistic. This innovative thought could open up the possibility to combat social evil and global differences caused by wrong attitude of man and also drive down the pessimistic attitude and prevailing unlawful norms of people in order to ensure the epithet that people of multifarious culture, religion and nationalities will have to come together and realize that we are a part of a one human family (Vasudeva kutambaya). We must believe that besides egoistical state of human existence, there exist another state of self-realization and self- concentration that in a center of tranquility, serenity, self-knowledge and true awareness where we feel true freedom from fear, ego, tension, inequities and complexity that truly cultivate the spirit of service. Let us do as much good as we can, to as many as we can, in as many ways as we can either in action or in thought, either in physical manifestation or in mental curiosity.

\title{
References
}

[1] Bhabe Vinoba, " Talk On The Gita", Paramdham Prakashan, wardha, 2003

[2] Besant Annie \& Das Bhagavam, "Sanatam Dharma: An Advanced Test Book for Hindu Religion and Ethics", The Theosophical Pub House, Chenai, 1940.

[3] Radhakrishnan S. "The Bhagavad-Gita”, Geoge Allen \& Unwin Ltd, 1948.

[4] Tilak, B.G, "Gita Rahasya", Keshari Press, Pune, 1915.

[5] Russell. B., "New Hopes For A Changing world", Geoge Allen \& Unwin Ltd, 1951.

[6] Swami. Prabhupada., Bhagavad-Gita As It Is" Bhaktivedanta Book Trust.

[7] Gandhi, M . K., "The Story Of My Experiment With Truth", Navajivam Pub House., Ahembad, 1927.

[8] Vivekanada, Swami., "What is Religion", Advata Ashrama Pub, Kolkotta, 1972.

*Corresponding author.

E-mail address: jatinlb1975@yahoo.co.in 